\title{
PERANCANGAN DAN PEMBUATAN SISTEM KOMPETISI SEPAK BOLA BERBASIS WEB
}

\author{
Yudho Yudhanto \\ Fakultas MIPA, Program Studi D3 Teknik Informatika \\ Universitas Negeri Sebelas Maret \\ Email: yuda@mipa.uns.ac.id \\ Andesta Putra \\ Fakultas MIPA, Program Studi D3 Teknik Informatika \\ Universitas Negeri Sebelas Maret \\ Email: andestap73@gmail.com
}

\begin{abstract}
ABSTRAK
Sepak bola merupakan salah satu cabang olahraga yang paling terkenal di dunia. Di Indonesia, olahraga ini sudah menjadi sebuah permainan yang disukai masyarakat dari berbagai lapisan umur. Namun dari berbagai turnamen yang telah diselenggarakan, terdapat beberapa kekurangan salah satunya adalah ketiadaan mengenai jadwal dan data statistik pertadingan secara lengkap yang dapat diketahui secara cepat oleh penggemar sepak bola, pengamat sepak bola, pengurus klub maupun pemain itu sendiri. Oleh karena itu, perlu adanya sistem untuk mempermudah proses penyampaian segala informasi mengenai kompetisi sepak bola yang berlangsung kepada para aktor sepak bola.

Implementasi dari pembuatan sebuah sistem kompetisi sepak bola berbasis web menggunakan PHP dan $M y S Q L$ yang mampu memberikan informasi mengenai data statistik pertandingan dari kompetisi secara lengkap dan dapat diakses dengan cepat oleh para aktor sepak bola.
\end{abstract}

Kata kunci: Kompetisi Sepak Bola, Sistem Informasi, Web.

\section{ABSTRACT}

Football is one of the most famous sport in the world. In Indonesia, this sport has become a favored game that people of all ages. However, from the various tournaments that have been held, there are some drawbacks one of which is the lack of statistical data regarding the schedule and complete pertadingan that can be known quickly by football fans, football observers, club officials and players themselves. Therefore, the need for a system to simplify the process of delivering all the information about the competition of football going to the actors of football.

Implementation of the creation of a system of web-based football competition using PHP and MySQL that can provide information on the match statistics from the competition is complete and can be accessed quickly by the actors of football.

Keywords: Football Competition, Information Systems, Web.

\section{PENDAHULUAN}

Sepak bola merupakan salah satu cabang olahraga yang paling terkenal di dunia. Di Indonesia, olahraga ini sudah menjadi sebuah permainan yang disukai masyarakat dari berbagai lapisan umur. Terdapat banyak turnamen sepak bola yang diselenggarakan setiap tahun oleh berbagai instansi baik mulai dari tingkat kecamatan sampai tingkat internasional. 
Namun dari berbagai turnamen yang telah diselenggarakan, terdapat beberapa kekurangan salah satunya adalah ketiadaan mengenai jadwal dan data statistik pertadingan secara lengkap yang dapat diketahui secara cepat oleh penggemar sepak bola, pengamat sepak bola, pengurus klub maupun pemain itu sendiri.

Teknologi web merupakan sistem informasi dan komunikasi hypertext dengan menggunakan jaringan internet. Terdapat banyak aplikasi yang telah menggunakan teknologi ini yang biasa disebut dengan aplikasi web. Keunggulan dari aplikasi web ialah pengguna dapat menggunakannya dimanapun tanpa penginstalan serta dapat diakses secara cepat melalui komputer atau smartphone.

Teknologi ini dapat menjadi solusi bagi permasalahan yang ada pada kompetisi sepak bola saat ini. Solusi yang diusulkan ialah dengan pembuatan sebuah sistem kompetisi sepak bola berbasis web menggunakan PHP dan MySQL sehingga dapat memberikan informasi mengenai data statistik pertandingan dari kompetisi secara lengkap dan dapat diakses dengan cepat oleh para aktor sepak bola. Perancangan sistem ini menggunakan MySQL sebagai database sehingga setiap pencatatan data statistik pertandingan akan disimpan oleh sistem ke dalam database sebagai arsip kompetisi. Kemudian sistem ini menggunakan PHP yang memang dirancang untuk membangun sebuah aplikasi web yang dinamis. Harapannya dengan pembuatan sistem ini mampu memberikan kontribusi bagi perbaikan pengelolaan administrasi kompetisi.

\section{METODOLOGI PENELITIAN}

Pada penelitian ini digunakan Metode Waterfall dimana metode ini adalah model pengembangan sistem yang menjadi dasar atau awal untuk model pengembangan sistem lainnya ${ }^{[1]}$.. Berikut ini merupakan alur dari Waterfall Models :

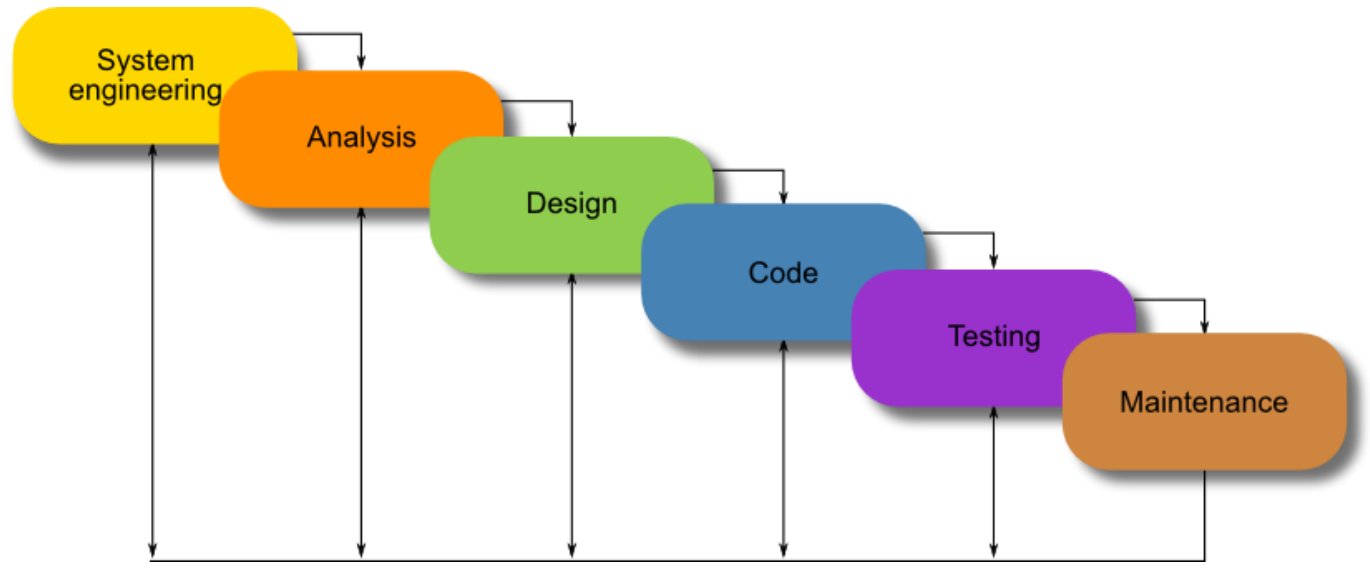

Gbr 1. Waterfall Models

Tahap pada yang terdapat pada Waterfall Models adalah sebagai berikut.

2.1. Studi Pustaka

Studi Pustaka merupakan tahap pengumpulan data dengan cara mencari lewat buku ataupun literature terkait dengan permasalahan dari objek penelitian.

2.2. Analisis kebutuhan

Tahap menganalisis setiap kebutuhan dari penelitian.

2.3. Melakukan perancangan

Tahap perancangan database serta tampilan user interface yang akan diimplementasikan kedalam sistem. 


\subsection{Pengkodean Sistem}

Tahap realisasi dengan melakukan pengkodean sistem menggunakan Bahasa pemrograman PHP.

2.5. Menguji Sistem

Tahap pengujian untuk menguji apakah sistem layak untuk dipakai atau tidak. Pada tahap ini penulis menggunakan pengujian dengan metode black box.

\section{HASIL DAN PEMBAHASAN}

\subsection{Proses Bisnis Aplikasi}

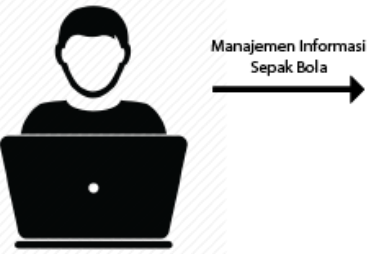

Admin
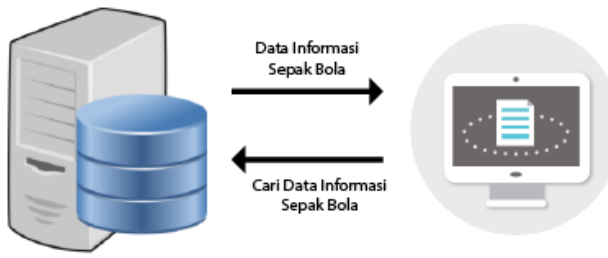

.

Gbr.2 Alur Proses Bisnis Sistem Informasi Kompetisi Sepak Bola

Dapat kita lihat pada proses bisnis diatas bahwa sistem informasi ini lebih berfokus pada penyampaian segala informasi yang berkaitan dengan kompetisi sepak bola. Admin memanajemen segala informasi tersebut kemudian menyimpannya kedalam database dan menampilkannya pada sistem informasi kompetisi sepak bola ini yang kemudian di konsumsi oleh guest atau pencinta sepak bola. Guest juga dapa berinteraksi dengan sistem untuk mencari informasi yang ia inginkan.

\subsection{Use Case}

Use Case menurut Martin Fowler (2005 : 141) adalah teknik untuk merekam persyaratan fungsional sebuah sistem ${ }^{[2]}$. Berikut ini merupakan use case pada sistema informasi kompetisi sepak bola. Pada use case diagram ini dapat kita ketahui yaitu terdapat 3 aktor yang berinteraksi dengan sistem ini. Aktor tersebut ialah super admin, admin, dan juga user/guest. Super admin dan admin dapat memanajemen segala informasi yang tersaji pada web kemudian guest dapat mencari setiap informasi sepak bola yang diinginkanya. Adapun kelebihan dari supe admin sendiri ialah superadmin dapat memanajemen akun admin lainnya. 
Indonesian Journal of Applied Informatics, Vol. 1 No. 2 Mei 2017

ISSN: 2548-3846

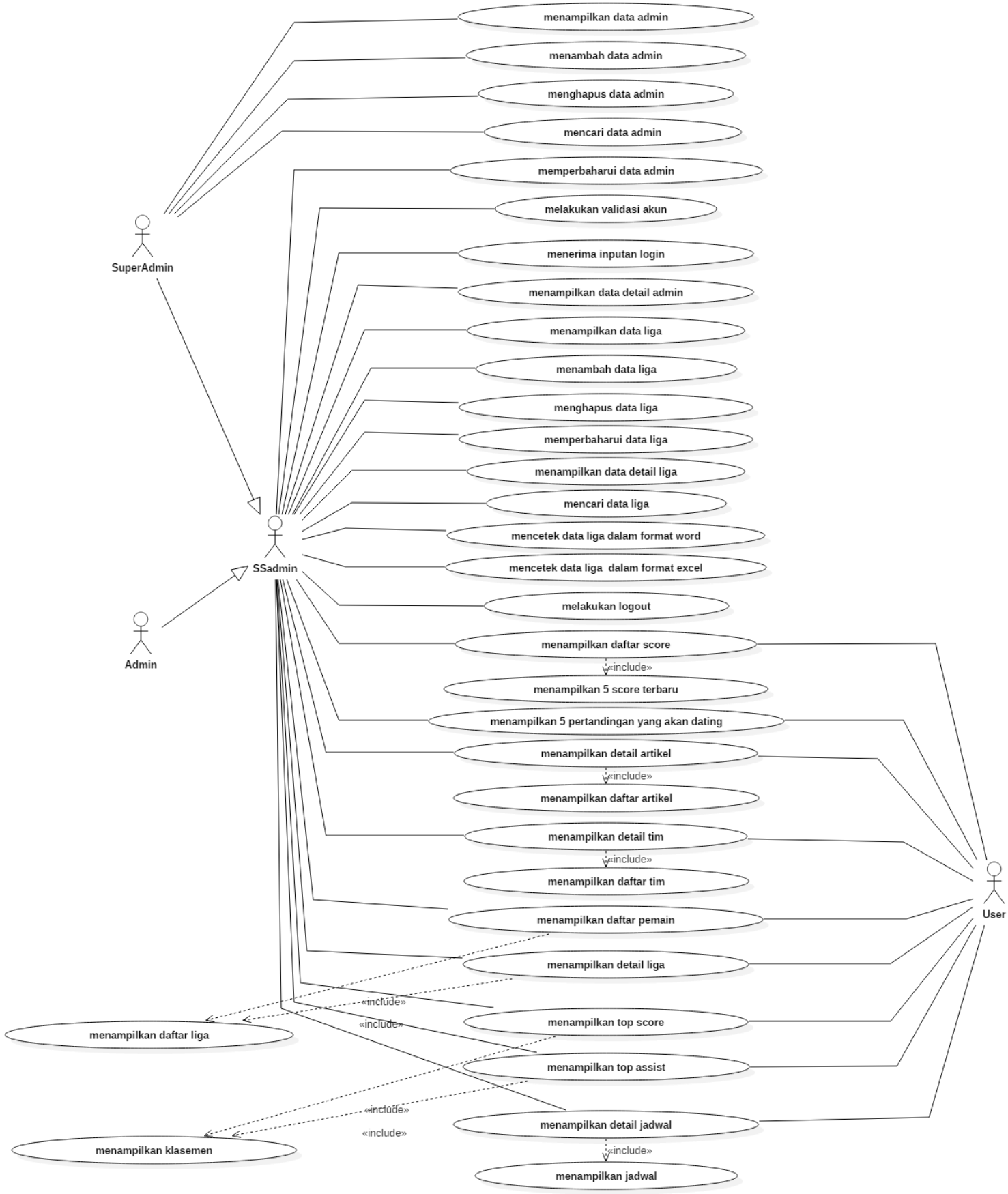

Gbr. 3 Use Case Sistem Informasi Kompetisi Sepak Bola 


\subsection{ERD}

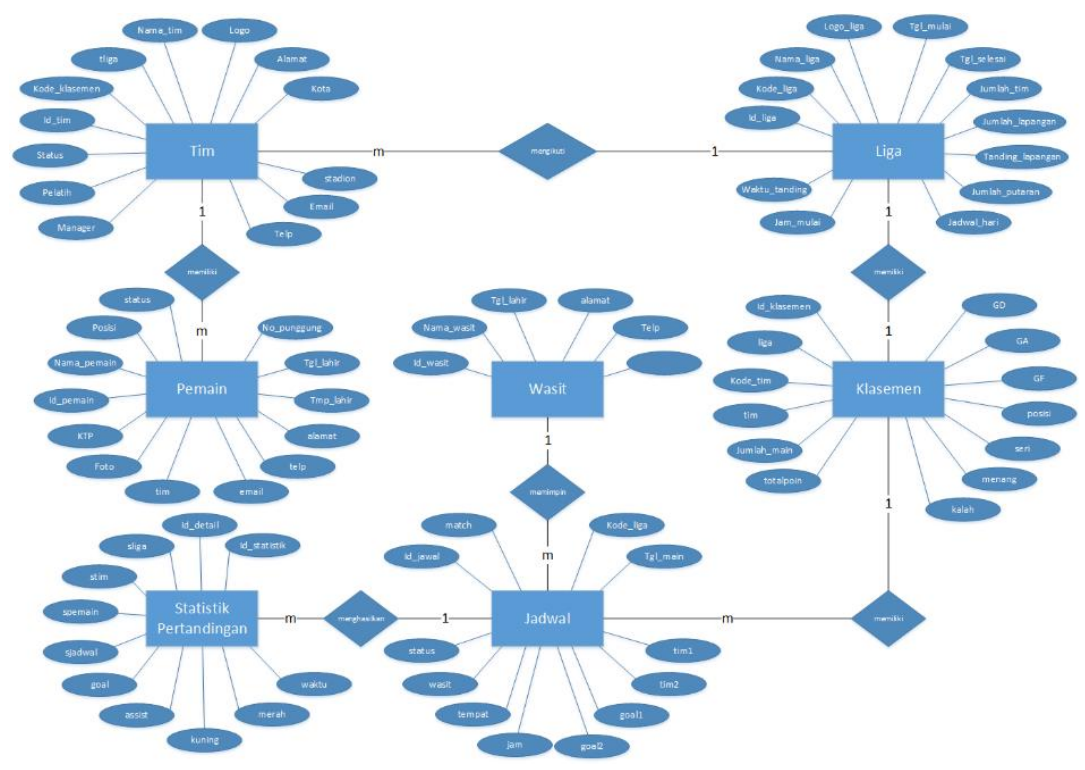

Gbr.4 ERD Sistem Informasi Kompetisi Sepak Bola

Menurut Sutanta (2011) "Entity Relationship Diagram (ERD) merupakan suatu model data yang dikembangkan berdasarkan objek." ${ }^{[3]}$ Entity Relationship Diagram (ERD) digunakan untuk menjelaskan hubungan antar data dalam basis data kepada pengguna secara logis. Entity Relationship Diagram (ERD) didasarkan pada suatu persepsi bahwa real world terdiri atas obyekobyek dasar tersebut. Penggunaan Entity Relationship Diagram (ERD) relatif mudah dipahami, bahkan oleh para pengguna yang awam. Bagi perancang atau analis sistem, Entity Relationship Diagram (ERD) berguna untuk memodelkan sistem yang nantinya, basis data akan di kembangkan. Model ini juga membantu perancang atau analis sistem pada saat melakukan analis dan perancangan basis data karena model ini dapat menunjukkan macam data yang dibutuhkan dan kerelasian antardata didalamnya.

Pada ERD diatas terdapat 7 entitas dimana masing-masing entitas akan mewakili satu tabel pada database dalam system ini. Terdapat beberapa kardinalitas pada ERD tersebut. Pada entitas pemain memiliki kardinalitas many-to-one terhadap entitas tim. Artinya banyak pemain hanya dapat memilih atau bermain satu tim atau satu tim terdiri dari banyak pemain. Kemudian entitas tim sendiri memiliki kardinalitas one-to-one dengan entitas liga. Artinya adalah setiap tim hanya dapat memiliki satu liga begitu juga sebaliknya. Untuk entitas liga dan klasemen terdapat kardinalitas one-to-one yaitu satu liga memiliki satu klasemen. Dilanjutkan ke entitas klasemen yang memiliki banyak jadwal pertandingan yang dinamankan kardinalitas one-to-many. 


\subsection{Relasi Tabel}

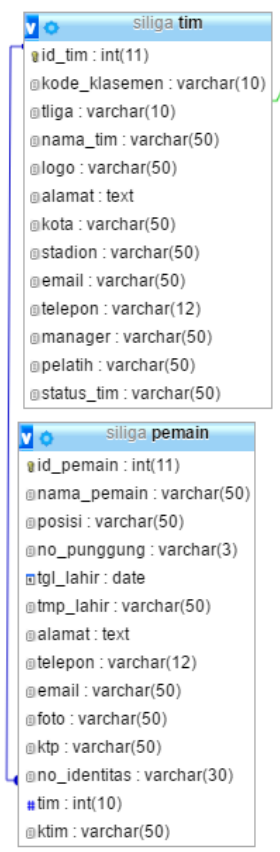

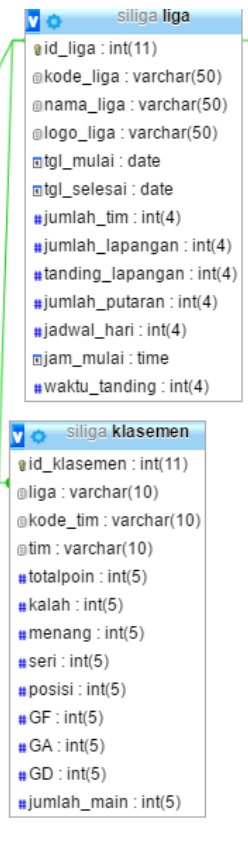

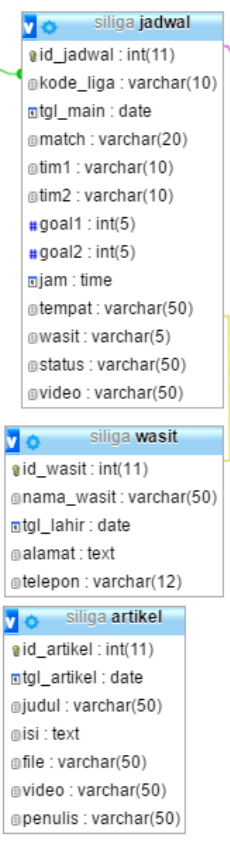

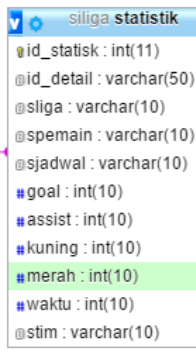

\section{Gbr.5 Relasi Antar Tabel Pada Sistem Informasi Kompetisi Sepak Bola}

Gambar diatas memperlihatkan relasi yang terdapat pada setiap tabel dalam perancangan database Sistem Informasi Kompetisi Sepak Bola ini.

\subsection{User Interface}

Pada sistem informasi kompetisi sepak bola ini terdapat dua tampilan utama yaitu tampilan admin dan juga tampilan guest. Tampilan admin berfungsi untuk mempermudah admin dalam mengelola setiap informasi yang akan disajikan pada sistem. Sedangkan tampilan guest untuk memberikan kenyamanan pada guest dalam mengkonsumsi setiap informasi kompetisi sepak bola yang disajikan. Berikut ini merupakan rancangan awal dan implementasi dari tampilan sistem informasi kompetisi sepakbola ini.
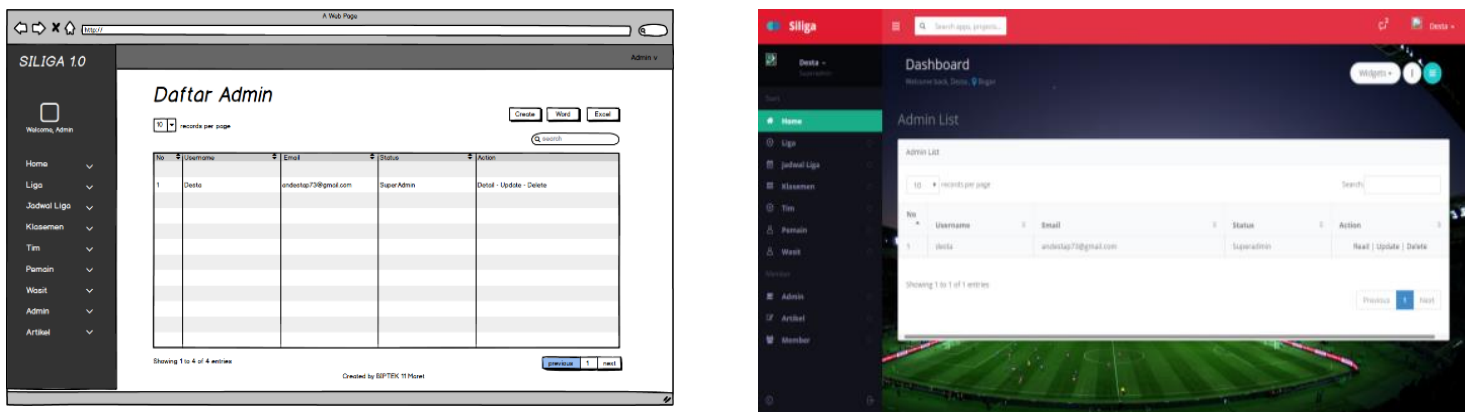

Gbr.6 Rancangan Halaman Admin dan Implementasi Halaman Admin 

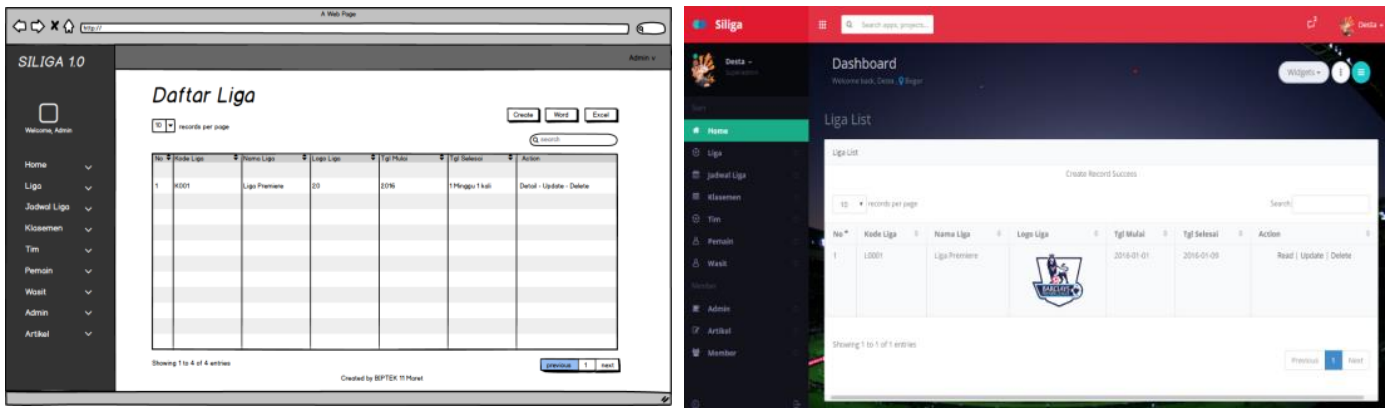

Gbr.7 Rancangan Halaman Liga dan Implementasinya
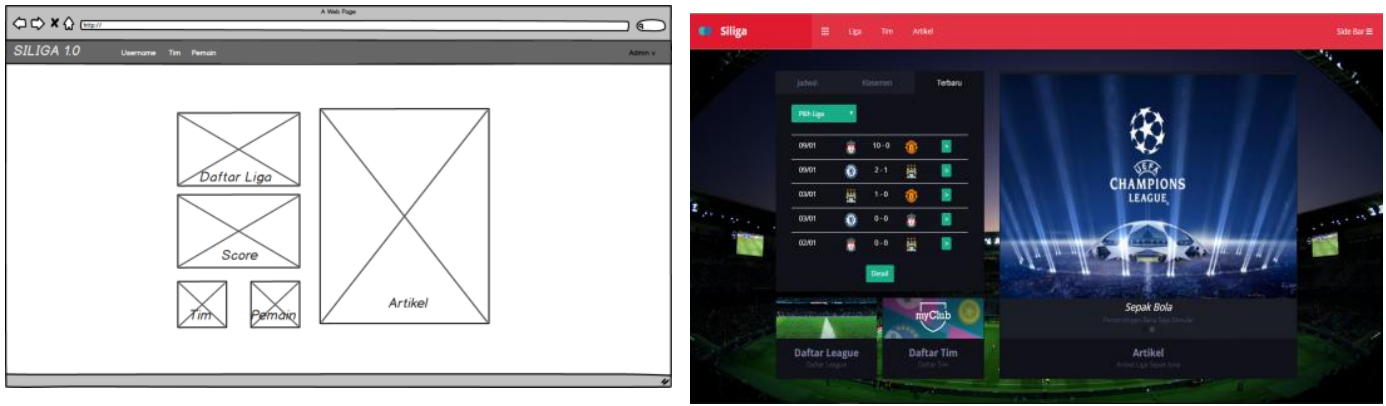

Gbr.8 Rancangan Halaman Utama Guest dan Implementasinya
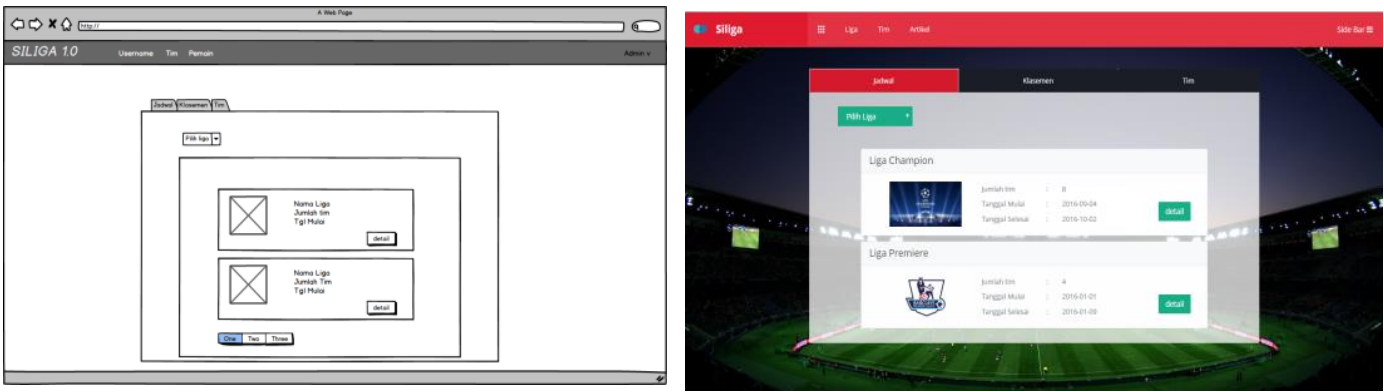

Gbr.9 Rancangan Halaman Liga Guest dan Implementasinya
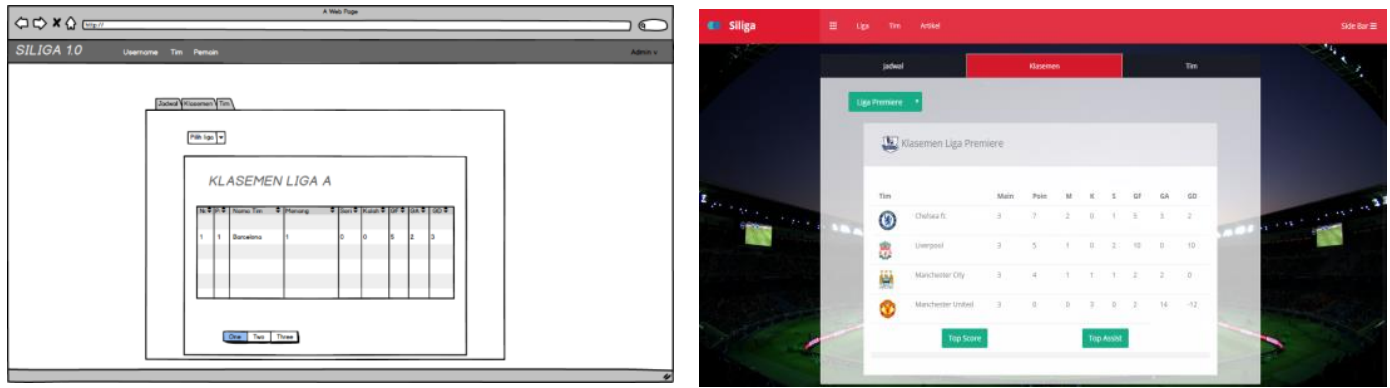

Gbr.10 Rancangan Halaman Klasemen Guest dan Implementasinya 


\subsection{Pengujian}

Pada pengujian sistem ini akan digunakan metode black box. Menurut Pressman (2010) Black-Box testing berfokus pada persyaratan fungsional perangkat lunak yang memungkinkan engineers untuk memperoleh set kondisi input yang sepenuhnya akan melaksanakan persyaratan fungsional untuk sebuah program ${ }^{[4]}$. Black-Box testing berusaha untuk menemukan kesalahan dalam kategori berikut:

1. Kesalahan dalam struktur data atau akses database eksternal

2. Kesalahan perilaku (behavior) atau kesalahan kinerja

3. Inisialisasi dan pemutusan kesalahan

\begin{tabular}{|c|c|c|c|c|c|}
\hline No & $\begin{array}{c}\text { Skenario } \\
\text { Pengujian }\end{array}$ & Test Case & $\begin{array}{l}\text { Hasil yang } \\
\text { diharapkan }\end{array}$ & $\begin{array}{c}\text { Hasil } \\
\text { Pengujian }\end{array}$ & Validasi \\
\hline 1 & $\begin{array}{l}\text { Mengosongkan } \\
\text { semua field pada } \\
\text { form login } \\
\text { kemudian menekan } \\
\text { tombol 'Sign in' }\end{array}$ & $\begin{array}{l}\text { Username: } \\
\text { (kosong) } \\
\text { Password: } \\
\text { (kosong) }\end{array}$ & $\begin{array}{l}\text { Sistem menolak } \\
\text { untuk masuk ke } \\
\text { halaman admin dan } \\
\text { muncul } \\
\text { pemberitahuan } \\
\text { bahwa username } \\
\text { dan password harus } \\
\text { diisi. }\end{array}$ & $\begin{array}{l}\text { Sesuai } \\
\text { harapan }\end{array}$ & $\begin{array}{l}\text { [ }] \text { Valid } \\
\text { [] Tidak } \\
\text { Valid }\end{array}$ \\
\hline 2 & $\begin{array}{l}\text { Mengisikan } \\
\text { username dan } \\
\text { mengosongkan } \\
\text { password } \\
\text { kemudian menekan } \\
\text { tombol 'Sign in' }\end{array}$ & $\begin{array}{l}\text { Username: } \\
\text { (username) } \\
\text { Password: } \\
\text { (kosong) }\end{array}$ & \begin{tabular}{|l|} 
Sistem menolak \\
untuk masuk ke \\
halaman admin dan \\
muncul \\
pemberitahuan \\
bahwa password \\
harus diisi.
\end{tabular} & $\begin{array}{l}\text { Sesuai } \\
\text { harapan }\end{array}$ & $\begin{array}{l}\sqrt{ } \text { ] Valid } \\
\text { [] Tidak } \\
\text { Valid }\end{array}$ \\
\hline 3 & $\begin{array}{l}\text { Mengosongkan } \\
\text { username dan } \\
\text { mengisikan } \\
\text { password } \\
\text { kemudian menekan } \\
\text { tombol 'Login' }\end{array}$ & $\begin{array}{l}\text { Username: } \\
\text { (kosong) } \\
\text { Password: } \\
\text { (password) }\end{array}$ & $\begin{array}{l}\text { Sistem menolak } \\
\text { untuk masuk ke } \\
\text { halaman admin dan } \\
\text { muncul } \\
\text { pemberitahuan } \\
\text { bahwa username } \\
\text { harus diisi. }\end{array}$ & $\begin{array}{l}\text { Sesuai } \\
\text { harapan }\end{array}$ & 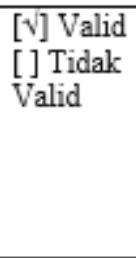 \\
\hline 4 & $\begin{array}{l}\text { Mengisikan } \\
\text { username benar } \\
\text { dan password salah } \\
\text { kemudian menekan } \\
\text { tombol 'Sign in' }\end{array}$ & $\begin{array}{l}\text { Username: } \\
\text { (username } \\
\text { benar) } \\
\text { Password: } \\
\text { (password } \\
\text { salah) }\end{array}$ & $\begin{array}{l}\text { Sistem menolak } \\
\text { untuk masuk ke } \\
\text { halaman admin dan } \\
\text { muncul } \\
\text { pemberitahuan } \\
\text { bahwa password } \\
\text { salah. }\end{array}$ & $\begin{array}{l}\text { Sesuai } \\
\text { harapan }\end{array}$ & 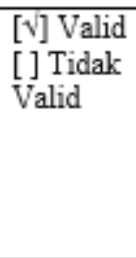 \\
\hline 5 & $\begin{array}{l}\text { Mengisikan } \\
\text { username salah } \\
\text { dan password } \\
\text { benar kemudian } \\
\text { menekan tombol } \\
\text { 'Sign in' }\end{array}$ & $\begin{array}{l}\text { Username: } \\
\text { (username } \\
\text { salah) } \\
\text { Password: } \\
\text { (password } \\
\text { benar) }\end{array}$ & $\begin{array}{l}\text { Sistem menolak } \\
\text { untuk masuk ke } \\
\text { halaman admin dan } \\
\text { muncul } \\
\text { pemberitahuan } \\
\text { bahwa username } \\
\text { salah. }\end{array}$ & $\begin{array}{l}\text { Sesuai } \\
\text { harapan }\end{array}$ & 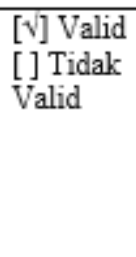 \\
\hline 6 & $\begin{array}{l}\text { Mengisikan } \\
\text { username benar } \\
\text { dan password } \\
\text { benar kemudian } \\
\text { menekan tombol } \\
\text { 'Sign in' }\end{array}$ & $\begin{array}{l}\text { Username: } \\
\text { (username } \\
\text { benar) } \\
\text { Password: } \\
\text { (password } \\
\text { benar) }\end{array}$ & $\begin{array}{l}\text { Sistem akan } \\
\text { menampilkan } \\
\text { halaman utama } \\
\text { admin sesuai } \\
\text { dengan akses level } \\
\text { dari setiap role akun } \\
\text { vang ada. } \\
\end{array}$ & $\begin{array}{l}\text { Sesuai } \\
\text { harapan }\end{array}$ & $\begin{array}{l}\text { [ }] \text { Valid } \\
\text { [] Tidak } \\
\text { Valid }\end{array}$ \\
\hline
\end{tabular}

Gbr.11 Pengujian Bagian Halaman Login 
Tabel diatas merupakan pengujian terhadap sistem login dengan metode black box testing. Semua skenario dari tabel pengujian diatas berjalan sesuai harapan. Jadi dari tabel pengujian black box ini dapat di ambil kesimpulan bahwa fitur sistem login pada sistem informasi kompetisi sepak bola ini bejalan baik dan sesuai harapan.

\begin{tabular}{|c|c|c|c|c|c|}
\hline No & $\begin{array}{l}\text { Skenario } \\
\text { Pengujian }\end{array}$ & Test Case & $\begin{array}{l}\text { Hasil yang } \\
\text { diharapkan }\end{array}$ & $\begin{array}{l}\text { Hasil } \\
\text { Pengujian }\end{array}$ & Validasi \\
\hline 1 & $\begin{array}{l}\text { Menginputkan } \\
\text { semua field } \\
\text { dengan benar } \\
\text { liga. }\end{array}$ & $\begin{array}{l}\text { Semua kolom } \\
\text { inputan diisi } \\
\text { dengan data } \\
\text { yang benar. } \\
\text { Tgl Mulai : } 1 \\
\text { januari 2016 } \\
\text { Jumlah tim : } 4 \\
\text { Jumlah } \\
\text { lapangan : } 2 \\
\text { Tanding } \\
\text { Lapangan : } \\
2 \\
\text { Jumlah } \\
\text { putaran : } \\
1 \\
\text { Jadwal hari : } \\
\text { Jam Mulai : } \\
\text { 13.00 PM } \\
\text { Waktu } \\
\text { tanding : } \\
90 \text { menit }\end{array}$ & $\begin{array}{l}\text { Sistem membuat } \\
\text { jadwal dengan jumlah } \\
\text { tim } 4 \text {, tanggal selesai } \\
\text { adalah tanggal } 1 \\
\text { september } 2016, \\
\text { setiap lapangan hanya } \\
\text { digunakan sebanyak } 2 \\
\text { kali dalam sehari, } \\
\text { pertandingan dimulai } \\
\text { dari jam } 13.0 \text { pm } \\
\text { dengan durasi tiap } \\
\text { pertandingan adalah } \\
90 \text { menit. Karena } \\
\text { jumlah putaran adalah } \\
1 \text { putaran maka setiap } \\
\text { tim mendapatkan } \\
\text { jadwal bertanding } \\
\text { sebanyak } 3 \text { kali. } \\
1 \text { putaran = (n-1) } \\
\text { pertandingan pertim. } \\
\text { Maka total permainan } \\
\text { dari liga adalah } 6 \\
\text { partai pertandingan. } \\
1 \text { putaran = (n } *(n-1)) \\
/ 2 \\
1 \text { putaran = (4* } 4 \text { (4- } \\
1)) / 2=6 \\
{ }^{n}=\text { jumlah tim }\end{array}$ & $\begin{array}{l}\text { Sesuai } \\
\text { harapan }\end{array}$ & $\begin{array}{l}\sqrt{ }] \text { Valid } \\
\text { [] Tidak } \\
\text { Valid }\end{array}$ \\
\hline
\end{tabular}

Gbr.12 Pengujian Generate Jadwal Pada Sistem Informasi Kompetisi Sepak Bola

Tabel diatas merupakan pengujian terhadap sistem generate jadwal liga dengan metode black box testing. Semua skenario dari tabel pengujian diatas berjalan sesuai harapan. Jadi dari tabel pengujian black box ini dapat di ambil kesimpulan bahwa fitur sistem generate jadwal liga pada sistem informasi kompetisi sepak bola ini bejalan baik dan sesuai harapan.

\section{KESIMPULAN}

Sistem Informasi Kompetisi Sepak Bola berbasis web telah selesai dibuat dengan menggunakan framewordk code igniter dengan fungsi utama untuk memberikan kemudahan kepada para pecinta sepak bola dalam mendapatkan informasi yang akurat dan cepat mengenai informasi kompetisi sepak bola. 


\section{DAFTAR PUSTAKA}

[1] Khurana, Gourav \& Gupta, Sachin., 2012. Study \& Comparisonof Software Development Life Cycle Models. iJREAS, 2(2).

[2] Fowler, Martin. 2005. UML Distilled Edisi 3.

[3] Sutanta, Edhy. 2011. Basis Data Dalam Tinjauan Konseptual.

[4] Pressman, R.S. (2010). Software Engineering : a practitioner's approach, 